\title{
Effects of climate change on the degree of protandry in migratory songbirds
}

\author{
Kalle Rainio ${ }^{1}$, Anders P. Tøttrup ${ }^{2}$, Esa Lehikoinen ${ }^{1}$, Timothy Coppack ${ }^{3, *}$ \\ ${ }^{1}$ Section of Ecology, Department of Biology, University of Turku, 20014 Turku, Finland \\ ${ }^{2}$ Center for Macroecology, Institute of Biology, University of Copenhagen, Universitetsparken 15, 2100 Copenhagen Ø, Denmark \\ ${ }^{3}$ Institute of Avian Research, An der Vogelwarte 21, 26386 Wilhelmshaven, Germany
}

\begin{abstract}
Current climate change is affecting the timing of life-history events of birds, such as the timing of spring arrival at the breeding grounds. Interspecific differences in the advancement of spring migration have hitherto been attributed to differences in exposure to climatic variables in winter or on migration, without a more detailed consideration of sex-specific differences in the timing and extent of migration. Since males and females migrate during different times of the season or may segregate into different wintering grounds, we expect climate change to differentially affect the arrival timing of males and females. Furthermore, sexual selection theory predicts that the degree of protandry (i.e. the time difference between male and female arrival) should increase when the forces of natural selection opposing early arrival relax and the earliest males benefit from improved mating opportunities. Here, we explore whether the degree of protandry has changed during a period of climatic warming using long-term phenological data collected at 5 North European bird observatories. We show for 4 sexually dichromatic songbird species that spring migration has generally advanced, but that the degree of protandry has not changed. Moreover, we provide evidence that variation in large-scale weather conditions, as reflected in the North Atlantic Oscillation (NAO) index, have not affected the degree of protandry. We hypothesize that a parallel shift in the timing of male and female migration may be due to similar phenotypic plastic responses of males and females to climatic changes or reflect a correlated selection response in males and females. In addition, we discuss the possibility that the observed variation in protandry could result from seasonal shifts in local environmental conditions under which birds of both sexes 'fall out' and are sampled.
\end{abstract}

KEY WORDS: Differential migration - Ficedula hypoleuca - Lanius collurio - Migration timing · Phenology $\cdot$ Phoenicurus phoenicurus $\cdot$ Protandry $\cdot$ Sylvia atricapilla

\section{INTRODUCTION}

Recent studies on avian phenology show trends towards earlier spring arrival and breeding, which are generally attributable to the environmental changes caused by global warming (Walther et al. 2002, Parmesan 2006). In Europe, first arrival dates of Eurasian bird species have generally advanced during the last 30 to $40 \mathrm{yr}$ (Lehikoinen et al. 2004, Thorup et al. 2007, Rubolini et al. 2007, this issue). Similar results have been published from NE North America, where spring arrival of birds has advanced on average by $8 \mathrm{~d}$ during the 20th century (Butler 2003, Marra et al. 2005). Shortdistance migrants that overwinter in temperate and sub-tropical regions have generally advanced their arrival more than long-distance migrants (Lehikoinen et al. 2004), but several migrants returning from distant tropical winter quarters show equally strong responses (Stervander et al. 2005, Jonzén et al. 2006). It remains unclear to what degree these changes reflect immediate phenotypic responses or micro-evolutionary adaptations to changing environmental circumstances in breeding and non-breeding areas and while travelling between (Pulido \& Berthold 2004, Both 2007, Jonzén 
et al. 2007). Numerous studies have linked long-term trends in the overall timing of spring migration and breeding to seasonal shifts in climatic conditions and resource availability (Coppack \& Both 2002, Lehikoinen et al. 2004, Visser et al. 2004). Yet, the withinseason complexity of phenological patterns has, so far, received only limited attention (MacMynowski \& Root 2007, Thorup et al. 2007).

Males of many migratory organisms, including the majority of songbirds, arrive on the breeding grounds before female conspecifics - a phenomenon termed protandry (Morbey \& Ydenberg 2001). Avian protandry is usually explained by the 'rank advantage' hypothesis, which states that male-male competition over high-quality territories selects for the earliest arriving males (Morbey \& Ydenberg 2001). However, selection could also act directly on the relative arrival of males and females in cases where males are polygynous and gain fitness benefits from earlier spring arrival with reduced sperm competition and increased opportunities for extra-pair copulations ('mate opportunity' hypothesis, see Morbey \& Ydenberg 2001, Rubolini et al. 2004, Coppack et al. 2006, Kokko et al. 2006).

Intersexual time differences in migration potentially expose males and females of the same species to different patterns of climatic change, since both sexes pass through different latitudes and climatic conditions at different times of the year. Moreover, in cases where the sexes segregate into different wintering latitudes, with males typically wintering closer to the breeding grounds than females (Ketterson \& Nolan 1976, Catry et al. 2005, Komar et al. 2005), males and females experience different climatic conditions throughout the entire non-breeding period. Any change in the relative arrival timing of males and females in immediate response to changing environmental conditions in winter or during migration (Ahola et al. 2004) will influence subsequent mating opportunities, with consequences for reproductive success, individual fitness and population viability.

Since the extent of protandrous migration can be viewed as a trait reflecting a balance between sexual and natural selection (Morbey \& Ydenberg 2001, Coppack et al. 2006, Kokko et al. 2006, Møller 2007), we may expect the time lag between male and female arrival to increase when sexual selection outweighs the opposing forces of natural selection (Møller 2004, 2007). Recently, Møller (2004) showed that protandry had increased over the past 2 decades in a Danish barn swallow Hirundo rustica population, suggesting that the environmental constraints opposing earlier male arrival have relaxed and selection on male earliness has intensified. This assumption was supported by a parallel change of a sexually selected characteristic, i.e. tail length, which showed a trend towards larger values (Møller 2004, Møller \& Szép 2005). However, at the interspecific level, Spottiswoode et al. (2006) found that the relationship between the advancement of spring migration and the strength of sexual selection was stronger for changes in the median migration date of whole populations than for changes in the timing of first-arriving (male) individuals, suggesting that selection has not only acted on protandrous males.

In the present study, we explore whether the time lag between male and female migration of 4 sexually dichromatic songbird species has changed over a $20 \mathrm{yr}$ period of climatic warming. Using phenological data collected at 5 northern European bird observatories, we analyse long-term trends in the degree of protandry and explore whether the relative arrival timing of males and females is related to large-scale fluctuations in climatic conditions.

\section{MATERIALS AND METHODS}

\subsection{Phenological data}

We used phenological data from constant-effort ringing stations on Helgoland, North Sea $\left(54^{\circ} 10^{\prime} \mathrm{N}\right.$, $7^{\circ} 53^{\prime} E_{i}$ Germany) and Christiansø, southern Baltic Sea $\left(55^{\circ} 19^{\prime} \mathrm{N}, 15^{\circ} 11^{\prime} \mathrm{E}\right.$; Denmark), as well as from 3 Finnish bird observatories in the northern Baltic Sea:

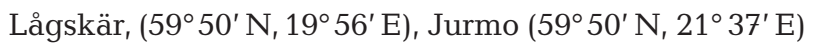
and Rönnskär ( $\left.59^{\circ} 56^{\prime} \mathrm{N}, 24^{\circ} 24^{\prime} \mathrm{E}\right)$.

We selected 4 sexually dimorphic migratory species for which adequate phenological data were available: redstart Phoenicurus phoenicurus, red-backed shrike Lanius collurio, blackcap Sylvia atricapilla and pied flycatcher Ficedula hypoleuca. Our analysis was confined to these 4 migratory species, because they are the only ones that can be readily sexed in the field and occurred in sufficient numbers at all latitudes.

In order to render data sets comparable, exactly the same span of years as available for Christiansø (1976 to 1997) was selected from all other sites that provide longer time series. To obtain continuous data sets for each spring, data from the Finnish observatories were pooled by calculating the daily mean number of birds trapped at all 3 sites. Phenological data from Christiansø and Helgoland (daily numbers of ringed individuals) were pooled by averaging median arrival dates, since these sites are situated at almost the same latitude. Pooling data from these 2 sites is also biologically justifiable, since ringing recoveries indicate that both migrant populations breed principally in Sweden and Finland (Zink 1973, Rabøl \& Rahbek 2002, Bønløkke et al. 2006, the Finnish Museum of Natural History unpubl. data), and those from Helgoland also farther west in Norway (Zink 1973), implying that they belong to the same over- 
all population (Spottiswoode et al. 2006). In the following, the Finnish data are referred to as 'north', and the combined data from Christiansø and Helgoland, as 'south'. Annual numbers of red-backed shrikes caught on Helgoland were considerably low, so that for this species, 'south' refers to data from Christiansø only.

\subsection{Analyses of protandrous migration}

We analysed sex-specific median migration dates, including geographical area, North Atlantic Oscillation (NAO) and year (and their interaction) as explanatory variables. Analyses were performed stepwise, whereby non-significant terms were dropped oneby-one, starting from the highest-level interaction until no term could be dropped.

The degree of protandry was calculated as the difference between median passage dates of females and males for each year between 1976 and 1997. We analysed changes in protandry by applying general linear models in which the degree of protandry was explained by year, winter NAO index (December to March, available from the website of the Climatic Research Unit at the University of East Anglia: www.cru.uea.ac.uk/cru/data/nao.htm) and area (north and south) with all interactions. Analyses were weighted by the yearly totals of trapped birds. In Europe, the NAO affects winter weather most (Hurrell et al. 2003) and can be viewed as a proxy for spring conditions (Hüppop \& Hüppop 2003, Stenseth et al. 2003). Using the NAO index closer to the actual migration period would appear more plausible, but shifting the NAO period closer to summer has little or no significant effect on the correlation coefficients between spring arrival of birds and the NAO (Rainio et al. 2006). The analyses were performed stepwise, similar to the sex-specific migration date analyses. We performed the analyses for each species separately.

\section{RESULTS}

Males of all 4 species arrived earlier than females, significantly in pied flycatcher Ficedula hypoleuca (north: $t=4.38, \mathrm{p}<0.001$; south: $t=3.24$, $\mathrm{p}=0.002$ ), redstart Phoenicurus phoenicurus (north: $t=5.78, \mathrm{p}<$ 0.001; south: $t=5.16, \mathrm{p}<0.001$ ) and blackcap Sylvia atricapilla in the south $(t=2.54, \mathrm{p}=0.014)$. The degree of protandry tended to be greater (statistically nonsignificant) in the south than in the north in all species except the pied flycatcher. The degree of protandry was greatest in the redstart $(7.8 \mathrm{~d}$ in the north and $8.1 \mathrm{~d}$ in the south) and lowest in the red-backed shrike Lanius collurio (2.0 d north, $2.5 \mathrm{~d}$ south) (Table 1).

The sex-specific analyses are summarised in Table 2. All interactions were dropped in the stepwise regression. In the redstart and the pied flycatcher, both sexes correlated with NAO variability, arriving earlier after winters with high NAO indices. Of these 2 species, only female redstarts showed a statistically significant trend towards earlier arrival. In the blackcap, both sexes showed statistically significant trends towards earlier arrival dates, but the NAO had no significant effect. The arrival of red-backed shrikes was neither significantly affected by the NAO, nor was there a statistically significant trend towards earliness. The arrival times were later in the north for all species, except the red-backed shrike.

We found no trends in the degree of protandry in any of the species studied (Figs. 1 \& 2, Table 3). Neither were there any statistically significant year-by-area interactions (Fig. 1, Table 3), indicating that the degree of protandry has remained unchanged in both areas. There were no significant NAO $\times$ Area interactions or main effects of NAO on the degree of protandry in the redstart, blackcap, or pied flycatcher. In the redbacked shrike, the NAO $\times$ Area interaction was statistically significant $\left(F_{1,38}=5.04, \mathrm{SE} \pm 0.47, \mathrm{p}=0.031\right)$, indicating different responses of protandry towards

Table 1. Mean of yearly protandry values with $95 \%$ CI, yearly range of observed individuals and mean passage dates of males and females in the 2 areas. The degree of protandry is measured as the difference in days between median passage dates of males and females

\begin{tabular}{|c|c|c|c|c|c|c|c|c|}
\hline \multirow[t]{2}{*}{ Taxon } & \multirow[t]{2}{*}{ Area } & \multirow{2}{*}{$\begin{array}{c}\text { Mean } \\
\text { protandry }\end{array}$} & \multirow{2}{*}{$\begin{array}{l}\text { Lower } \\
95 \% \text { CI }\end{array}$} & \multirow{2}{*}{$\begin{array}{c}\text { Upper } \\
95 \% \text { CI }\end{array}$} & \multicolumn{2}{|c|}{$\mathrm{N}$ range } & \multicolumn{2}{|c|}{ Passage date } \\
\hline & & & & & $0^{1} 0^{1}$ & 우 & $0^{1} 0^{1}$ & 우 \\
\hline Redstart & North & 7.8 & 6.2 & 9.3 & $156-365$ & $153-450$ & 15 May & 22 May \\
\hline Phoenicurus phoenicurus & South & 8.1 & 6.6 & 9.6 & $123-400$ & $171-540$ & 11 May & 19 May \\
\hline Blackcap & North & 3.5 & 2.1 & 5.0 & $45-252$ & $43-212$ & 24 May & 28 May \\
\hline Sylvia atricapilla & South & 4.6 & 2.7 & 6.5 & $85-425$ & $87-462$ & 14 May & 19 May \\
\hline Pied flycatcher & North & 5.9 & 4.1 & 7.8 & $49-285$ & $44-269$ & 15 May & 21 May \\
\hline Ficedula hypoleuca & South & 4.5 & 3.3 & 5.7 & $52-238$ & $72-254$ & 12 May & 16 May \\
\hline Red-backed shrike & North & 2.0 & 1.1 & 2.8 & $18-226$ & $10-243$ & 25 May & 27 May \\
\hline Lanius collurio & South & 2.5 & 1.3 & 3.8 & $12-112$ & $14-136$ & 26 May & 28 May \\
\hline
\end{tabular}


Table 2. Sex- and species-specific effects of area, North Atlantic Oscillation (NAO) and year on the median spring arrival times. The analyses were performed stepwise so that non-significant terms were removed one-by-one, starting from the highest-level interaction. Only main effects are reported; all interactions were non-significant. For full taxonomic names, see Table 1

\begin{tabular}{|c|c|c|c|c|c|c|c|}
\hline Species & Sex & Factor & Estimate & $\mathrm{SE}$ & $\mathrm{df}$ & $F$ & $\mathrm{p}$ \\
\hline \multirow[t]{6}{*}{ Redstart } & \multirow[t]{3}{*}{$0^{1}$} & Year & -0.11 & 0.10 & 1,40 & 1.24 & 0.272 \\
\hline & & NAO & -1.88 & 0.50 & 1,41 & 14.08 & $<0.001$ \\
\hline & & Area & 3.90 & 1.26 & 1,41 & 9.56 & 0.004 \\
\hline & \multirow[t]{3}{*}{ 우 } & Year & -0.24 & 0.10 & 1,40 & 5.70 & 0.022 \\
\hline & & NAO & -1.52 & 0.51 & 1,40 & 8.80 & 0.005 \\
\hline & & Area & 3.58 & 1.24 & 1,40 & 8.31 & 0.006 \\
\hline \multirow[t]{6}{*}{ Blackcap } & \multirow[t]{3}{*}{$0^{7}$} & Year & -0.37 & 0.13 & 1,41 & 7.96 & 0.007 \\
\hline & & NAO & -0.29 & 0.70 & 1,40 & 0.18 & 0.676 \\
\hline & & Area & 9.64 & 1.67 & 1,41 & 33.29 & $<0.001$ \\
\hline & \multirow[t]{3}{*}{ q } & Year & -0.44 & 0.12 & 1,41 & 12.76 & $<0.001$ \\
\hline & & NAO & -0.86 & 0.64 & 1,40 & 1.83 & 0.183 \\
\hline & & Area & 8.60 & 1.56 & 1,41 & 30.47 & $<0.001$ \\
\hline \multirow{6}{*}{$\begin{array}{l}\text { Pied } \\
\text { flycatcher }\end{array}$} & \multirow[t]{3}{*}{$0^{1}$} & Year & -0.09 & 0.52 & 1,40 & 0.73 & 0.399 \\
\hline & & NAO & -2.05 & 0.50 & 1,41 & 17.02 & $<0.001$ \\
\hline & & Area & 2.85 & 1.25 & 1,41 & 5.21 & 0.028 \\
\hline & \multirow[t]{3}{*}{ q } & Year & -0.03 & 0.09 & 1,40 & 0.12 & 0.730 \\
\hline & & NAO & -1.51 & 0.45 & 1,41 & 11.07 & 0.002 \\
\hline & & Area & 4.24 & 1.14 & 1,41 & 13.88 & 0.001 \\
\hline \multirow{6}{*}{$\begin{array}{l}\text { Red-backed } \\
\text { shrike }\end{array}$} & \multirow{3}{*}{$0^{7}$} & Year & -0.13 & 0.13 & 1,41 & 1.03 & 0.312 \\
\hline & & NAO & 0.81 & 0.68 & 1,40 & 1.43 & 0.238 \\
\hline & & Area & -0.92 & 1.67 & 1,39 & 0.30 & 0.586 \\
\hline & \multirow[t]{3}{*}{ ㅇ } & Year & -0.12 & 0.12 & 1,41 & 0.92 & 0.343 \\
\hline & & NAO & 0.23 & 0.66 & 1,39 & 0.13 & 0.725 \\
\hline & & Area & -1.52 & 1.58 & 1,40 & 0.93 & 0.341 \\
\hline
\end{tabular}

NAO variability in the 2 areas. In the north, the NAO index was negatively correlated with protandry $\left(b=-1.22, \mathrm{SE} \pm 0.25, F_{1,20}=23.72, \mathrm{p}<0.001\right)$; the degree of protandry was close to zero after high-NAO winters (Fig. 1), possibly because females tend to arrive earlier after such winters (Fig. 3). However, when sex-specific arrival times were analysed the $\mathrm{NAO} \times$ Sex interaction was not significant $\left(F_{1,39}=0.82\right.$, $\mathrm{p}=0.370$ ) (Fig. 3). In the south, the NAO had no significant effect on red-backed shrike protandry $(b=0.16$, $\mathrm{SE} \pm 0.59, F_{1,19}=0.15, \mathrm{p}=0.702$ (Fig. 1).

\section{DISCUSSION}

Males of all 4 species arrived earlier than females. The degree of protandry was greatest in the redstart Phoenicurus phoenicurus, $7.8 \mathrm{~d}$ in the north and $8.1 \mathrm{~d}$ in the south, and lowest in the red-backed shrike Lanius collurio, 2.0 and $2.5 \mathrm{~d}$, respectively (Table 1). These protandry values are larger than those reported for the Mediterranean islands by Rubolini et al. (2004), where protandry averages around $5 \mathrm{~d}$ in the redstart, around $4 \mathrm{~d}$ in the pied flycatcher Ficedula hypoleuca (versus $5.9 \mathrm{~d}$ in the northern and $4.5 \mathrm{~d}$ in the southern
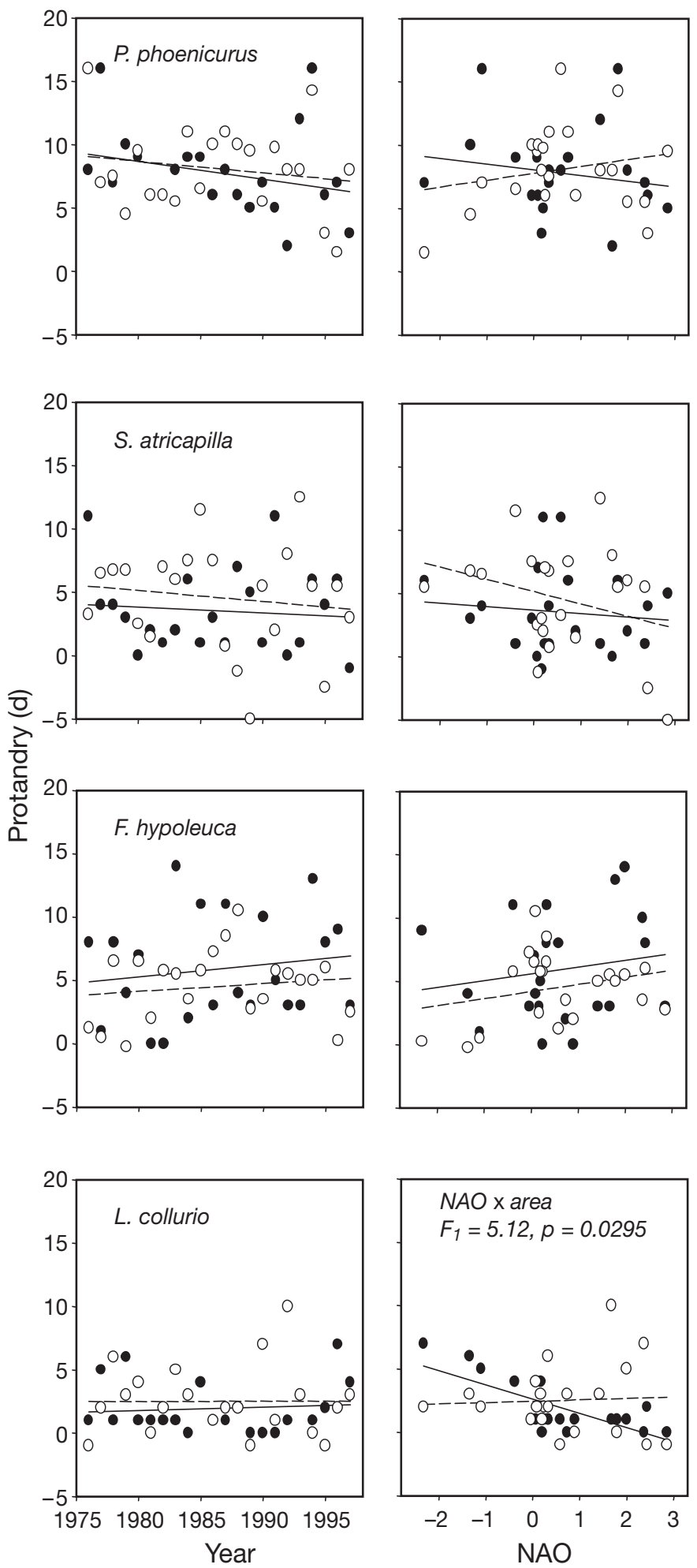

Fig. 1. Species-specific trends in protandry (the difference in days between median passage dates of males and females) from 1976 to 1997 and the effects of winter NAO (North Atlantic Oscillation) in the south (Christiansø, Denmark; and Helgoland, Germany: filled circles, solid line) and the north (Lågskär, Jurmo and Rönnskär, Finland: open circles, dashed line). For full taxonomic names, see Table 1 


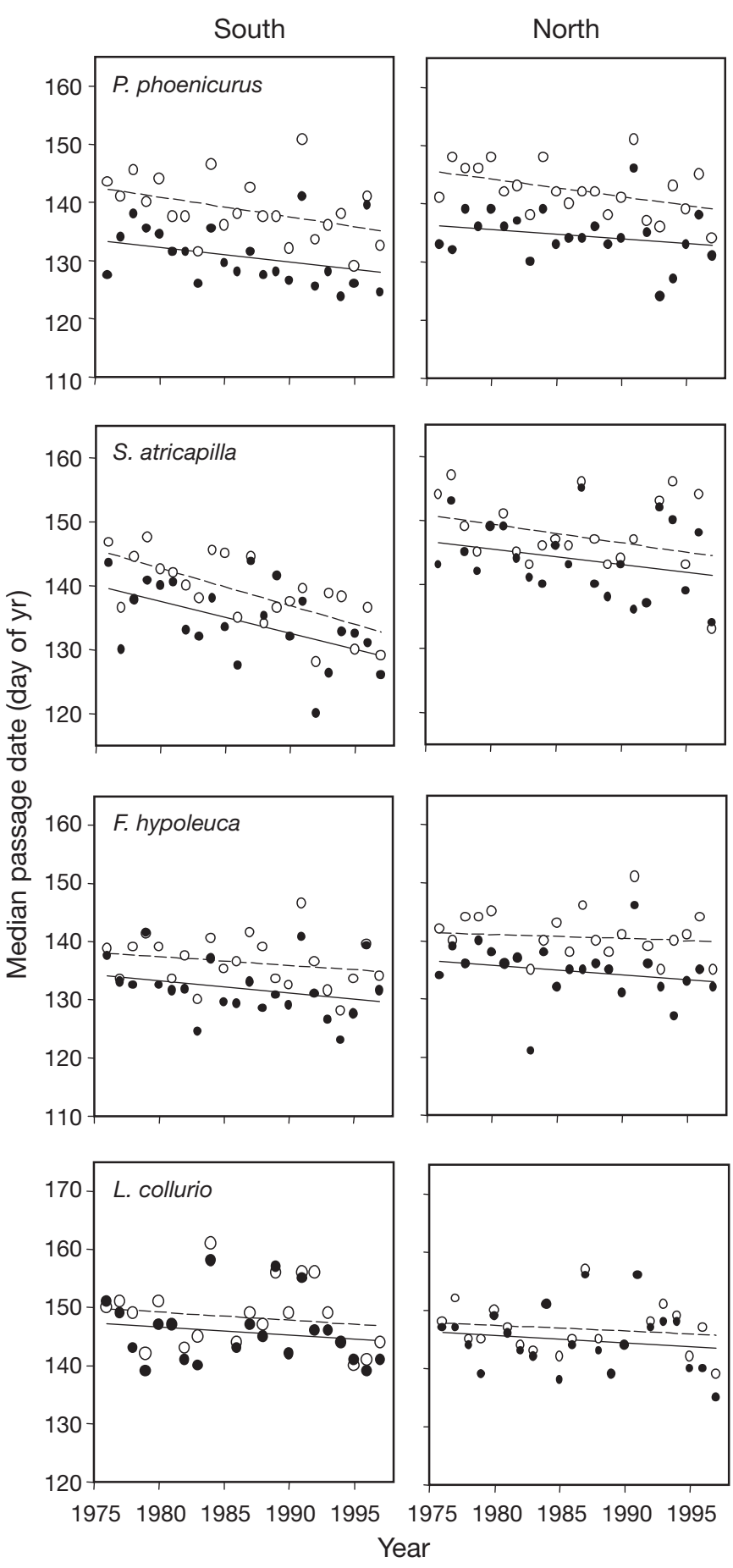

Fig. 2. Trends in sex-specific, median passage dates of 4 songbird species in the south (Christiansø, Helgoland) and the north (Lågskär, Jurmo, Rönnskär) from 1976 to 1997. Filled circles, solid line: males; open circles, dashed line: females

group of our study), and around $1 \mathrm{~d}$ in the blackcap Sylvia atricapilla (versus $3.5 \mathrm{~d}$ in the northern and $4.6 \mathrm{~d}$ in the southern group of our study). This general trend towards higher protandry values in northern Europe as compared to southern Europe may indicate that males
Table 3. Results of general linear modelling in which the degree of protandry was explained by year, winter NAO index and area. The analyses were performed stepwise, whereby non-significant terms were dropped one-by-one, starting from the highest-level interaction, and were weighted by yearly sample size

\begin{tabular}{|c|c|c|c|}
\hline Factor & df & $F$ & $\mathrm{p}$ \\
\hline \multicolumn{4}{|c|}{ Redstart Phoenicurus phoenicurus } \\
\hline Year $\times$ NAO $\times$ Area & 1,36 & 2.09 & 0.157 \\
\hline Year $\times$ Area & 1,37 & 0.00 & 0.993 \\
\hline Year $\times$ NAO & 1,38 & 1.75 & 0.194 \\
\hline $\mathrm{NAO} \times$ Area & 1,39 & 2.09 & 0.156 \\
\hline Area & 1,40 & 0.25 & 0.619 \\
\hline NAO & 1,41 & 0.30 & 0.584 \\
\hline Year & 1,42 & 2.48 & 0.123 \\
\hline \multicolumn{4}{|c|}{ Blackcap Sylvia atricapilla } \\
\hline \multicolumn{4}{|c|}{ Removed fixed effects } \\
\hline Year $\times$ NAO $\times$ Area & 1,36 & 0.17 & 0.681 \\
\hline Year $\times$ NAO & 1,37 & 0.00 & 0.958 \\
\hline $\mathrm{NAO} \times$ Area & 1,38 & 0.13 & 0.725 \\
\hline Year × Area & 1,39 & 0.24 & 0.628 \\
\hline Year & 1,40 & 0.02 & 0.886 \\
\hline Area & 1,41 & 0.49 & 0.487 \\
\hline NAO & 1,42 & 1.06 & 0.309 \\
\hline \multicolumn{4}{|c|}{ Pied flycatcher Ficedula hypoleuca } \\
\hline Year $\times$ NAO $\times$ Area & 1,36 & 0.33 & 0.570 \\
\hline $\mathrm{NAO} \times$ Area & 1,37 & 0.05 & 0.818 \\
\hline Year × Area & 1,38 & 0.34 & 0.566 \\
\hline Year $\times$ NAO & 1,39 & 0.66 & 0.423 \\
\hline NAO & 1,40 & 0.62 & 0.436 \\
\hline Area & 1,41 & 0.98 & 0.328 \\
\hline Year & 1,42 & 1.39 & 0.246 \\
\hline \multicolumn{4}{|c|}{$\begin{array}{l}\text { Red-backed shrike Lanius collurio } \\
\text { Fixed effects-final model }\end{array}$} \\
\hline Year & 1,38 & 0.50 & 0.485 \\
\hline $\mathrm{NAO}$ & 1,38 & 9.00 & 0.005 \\
\hline Area & 1,38 & 0.30 & 0.586 \\
\hline $\mathrm{NAO} \times$ Area & 1 & 5.04 & 0.031 \\
\hline \multicolumn{4}{|l|}{ Removed fixed effects } \\
\hline Year $\times \mathrm{NAO} \times$ Area & 1,35 & 0.83 & 0.369 \\
\hline Year $\times$ Area & 1,36 & 0.19 & 0.667 \\
\hline Year $\times$ NAO & 1,37 & 1.32 & 0.259 \\
\hline
\end{tabular}

and females migrate at different speeds, in which case males would stopover less frequently and for shorter periods than females. However, comparisons between phenological estimates at different localities and time periods must be handled with caution, since birds passing different observatories at different times of the year may not belong to the same overall breeding populations and may be subject to different ecological conditions and selection regimes. Furthermore, our study only considers sexually dichromatic species, which can be readily sexed in the field. Rubolini et al. (2004) have shown that more dichromatic species tend to be more protandrous. Thus, our sample of species might be non-random with respect to the strength of sexual selection that influences protandry (cf. Coppack et al. 2006). 

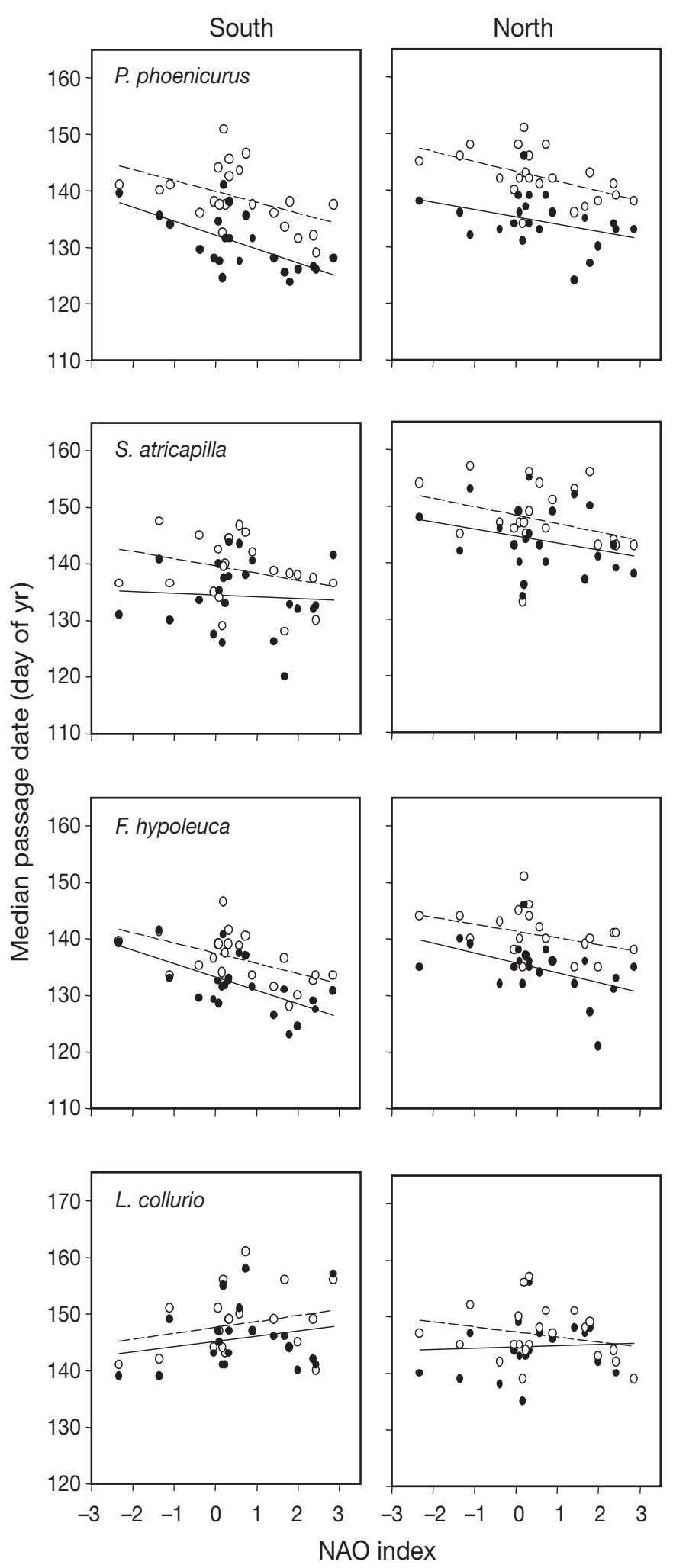

Fig. 3. Sex-specific, median passage dates of 4 songbird species in the south (Christiansø, Helgoland) and the north (Lågskär, Jurmo, Rönnskär) in relation to the winter NAO index (1976 to 1997). Filled circles, solid line: males; open circles, dashed line: females

\subsection{Long-term trends in protandry}

We found no effect of year on the degree of protandry in any of the 4 long-distance migrant songbird species under study, meaning that during the last decades there has not been any consistent change in the arrival time difference between males and females. Thus, recent changes in environmental conditions appear to have affected both sexes in a similar way. This general pattern differs from the results of Møller (2004), who found that the degree of protandry in a Danish barn swallow population had increased during the last decades of climate warming.

There are 3 hypothetical, not mutually exclusive, explanations why we did not detect any consistent changes in protandry despite the overall trend towards earlier migration. (1) Both sexes show similar phenotypic plastic responses to environmental changes at the wintering grounds and/or en route. (2) Selection has acted on both sexes to the same degree. (3) Local conditions under which birds of both sexes 'fall out' have advanced, leading to parallel a shift in sampling frequency.

Hypotheses 1 and 2 assume that migratory birds are actually shifting the mean timing of their migration (see Fig. 4a) and that males and females of the same species are responding to phenological changes in their environment in the same way. Changes in migratory behaviour could be taking place at a phenotypically plastic level (Hypothesis 1), for instance, through an increase in migration speed due to milder conditions en route (see Ahola et al. 2004, Marra et al. 2005, Hüppop \& Winkel 2006) and/or through selection on the timing mechanism of spring migration (Hypothesis 2 ), which would involve genetic changes in circannual rhythms and cue response thresholds (van Noordwijk 2003, Pulido 2007a). These 2 alternatives cannot be distinguished by analysing trapping numbers that do not include repeated measurements of individuals (see Pulido 2007b, this issue).

In the third case (Hypothesis 3), we assume that the climatic conditions under which birds of both sexes 'fall out' and stopover have shifted, with the consequence that both males and females are sampled earlier in the season (see Fig. 4b). Under this assumption, phenological changes in spring passage would not involve populational changes in behaviour or physiology, but would simply reflect changes in local sampling conditions, resulting in different observation frequencies at different times of the year. If, however, males migrate earlier than females, proportionally more males should be trapped earlier in the season, potentially leading to an inflation of protandry. This prediction could be tested by analysing trends in sex ratios relative to the degree of protandry. 

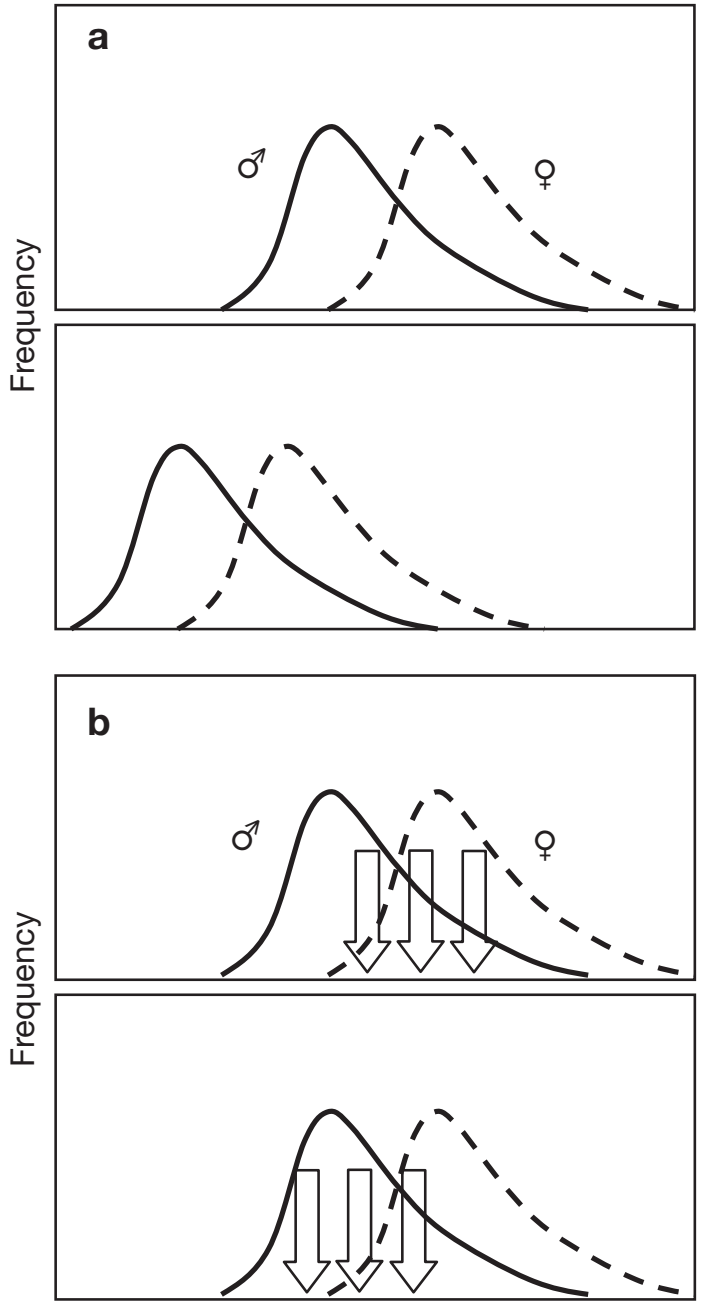

Time of year

Fig. 4. Hypothetical frequency distributions of male and female migrants, showing at which levels overall phenology and the degree of protandry may change: (a) the timing of migration of the entire population shifts; (b) no changes in 'true' migration, but a change in local sampling conditions occurs, causing males and females to 'fall out' earlier (arrows)

Generally, the question of whether migrants have changed their behaviour or whether climate change has simply altered the conditions under which certain fractions of migratory populations are observed needs further attention (see Knudsen et al. 2007, this issue).

\subsection{The effect of NAO on protandry}

The effect of the NAO on the degree of protandry was not significant in most cases. The sex-specific response slopes are parallel, which indicates a similar response of both sexes to fluctuation of the NAO. How- ever, in the red-backed shrike, the NAO $\times$ Area interaction remained significant in the model, indicating that change in protandry in relation to the NAO was different between northern and southern trapping sites. At northern sites, the degree of protandry seems to be smaller after high-NAO winters; females are advancing, while males are not, and so the females are catching up to the males and arriving at breeding areas at approximately the same time as males (Fig. 3). This could lead to situations where males have less time to find and defend high-quality territories before potential mates arrive.

The responses in arrival time to the NAO fade with the progression of the migration season, i.e. early fractions of migratory populations are more sensitive to fluctuations in the NAO (Vähätalo et al. 2004, Rainio et al. 2006, Tøttrup et al. 2006). This fading of response could result from increased protandry (Rainio et al. 2006) - males would be more sensitive to the overall advancement in phenology, which they experience along their migration route after high-NAO winters, thus shifting the early part of migratory populations towards earlier arrival. Since we did not detect significant changes in the degree of protandry, its role may not be an important factor creating different phase responses. However, Rubolini et al. (2007) showed that the arrival time responses of birds to climate change are species specific: when the effects of phylogeny were analysed, the most important taxonomic level was species. Thus, the results of our study may not apply to other species.

In conclusion, our results suggest that protandry has not changed in populations of migrating songbirds. However, phenological data collected at bird observatories do not include information on how individual males and females behave in different years and on how progeny of known origin deviates from its midparent value. This information is needed to be able to distinguish between phenotypic plastic responses and genetic (evolutionary) processes that underlie recent phenological changes in response to global environmental change (Pulido 2007b). Thus, we need to continue established - and initiate new-long-term studies that follow-up life-history and behavioural traits in individually marked or tracked bird populations.

Acknowledgements. We thank the Ringing Centre of the Finnish Museum of Natural history for providing the data for the 3 Finnish bird observatories. We thank all ornithologists and volunteers at Lågskär, Jurmo, Rönnskär; at Vogelwarte Helgoland; and at Christiansø Research Station (the latter financed by The Danish National and Nature Agency and The National Environmental Research Institute) who have contributed to the collection and maintenance of phenological data. Four anonymous referees provided valuable comments on an earlier version of the manuscript. 


\section{LITERATURE CITED}

Ahola M, Laaksonen T, Sippola K, Eeva T, Rainio K, Lehikoinen E (2004) Variation in climate warming along the migration route uncouples arrival and breeding dates. Glob Change Biol 10:1610-1617

Bønløkke B, Madsen JJ, Thorup K, Pedersen KT, Bjerrum M, Rahbek C (2006) Dansk Trækfugleatlas [The Danish Bird Migration Atlas]. Rhodos A/S and Zoological Museum, University of Copenhagen. Narayana Press, Copenhagen

Both C (2007) Comment on 'Rapid advance of spring arrival dates in long-distance migratory birds'. Science 315:598

Butler CJ (2003) The disproportionate effect of global warming on the arrival dates of short-distance migratory birds in North America. Ibis 145:484-495

Catry P, Lecoq M, Araujo A, Conway G and others (2005) Differential migration of chiffchaffs Phylloscopus collybita and P. ibericus in Europe and Africa. J Avian Biol 36: 184-190

Coppack T, Both C (2002) Predicting life-cycle adaptation of migratory birds to global climate change. Ardea 90: 369-378

Coppack T, Tøttrup AP, Spottiswoode C (2006) Degree of protandry reflects level of extrapair paternity in migratory songbirds. J Ornithol 147:260-265

Hüppop O, Hüppop K (2003) North Atlantic Oscillation and timing of spring migration in birds. Proc R Soc Lond B Biol Sci 270:233-240

Hüppop O, Winkel W (2006) Climate change and timing of spring migration in the long-distance migrant Ficedula hypoleuca in central Europe: the role of spatially different temperature changes along migration routes. J Ornithol 147:344-353

Hurrell JW, Kushnir Y, Ottersen G, Visbeck M (2003) An overview of the North Atlantic Oscillation. In: Hurrell JW, Kushnir Y, Ottersen G, Visbeck M (eds) The North Atlantic Oscillation: climatic significance and environmental impact. American Geophysical Union, Washington, DC, p 1-35

Jonzén N, Linden A, Ergon T, Knudsen E and others (2006) Rapid advance of spring arrival dates in long-distance migratory birds. Science 312:1959-1961

Jonzén N, Linden A, Ergon T, Knudsen E and others (2007) Response to comment on 'Rapid advance of spring arrival dates in long-distance migratory birds'. Science 315:598

Ketterson ED, Nolan V Jr (1976) Geographic variation and its climatic correlates in the sex ratio of eastern-wintering dark-eyed juncos (Junco hyemalis hyemalis). Ecology 57: 679-693

Knudsen E, Lindén A, Ergon T, Jonzén N and others (2007) Characterizing bird migration phenology using data from standardized monitoring at bird observatories. Clim Res 35:59-77

Kokko H, Gunnarsson TG, Morrell LJ, Gill JA (2006) Why do female migratory birds arrive later than males? J Anim Ecol 75:1293-1303

Komar O, O'Shea BJ, Peterson AT, Navarro-Siguenza AG (2005) Evidence of latitudinal sexual segregation among migratory birds wintering in Mexico. Auk 122:938-948

Lehikoinen E, Sparks TH, Zalakevicius M (2004) Arrival and departure dates. Adv Ecol Res 35:1-31

MacMynowski DP, Root T (2007) Climate and the complexity of migratory phenology: sexes, migratory distance, and arrival distributions. Int J Biometeorol 51:361-373

Marra PP, Francis CM, Mulvihill RS, Moore FR (2005) The influence of climate on the timing and rate of spring bird migration. Oecologia 142:307-315

Møller AP (2004) Protandry, sexual selection and climate change. Glob Change Biol 10:2028-2035

Møller AP (2007) Tardy females, impatient males: protandry and divergent selection on arrival date in the 2 sexes of the barn swallow. Behav Ecol Sociobiol 61:1311-1319

Møller AP, Szép T (2005) Rapid evolutionary change in a secondary sexual character linked to climatic change. J Evol Biol 18:481-495

Morbey YE, Ydenberg RC (2001) Protandrous arrival timing to breeding areas: a review. Ecol Lett 4:663-673

Parmesan C (2006) Ecological and evolutionary responses to recent climate change. Annu Rev Ecol Syst 37:637-669

Pulido F (2007a) The genetics and evolution of avian migration. Bioscience 57:165-174

Pulido F (2007b) Phenotypic changes in spring arrival: evolution, phenotypic plasticity, effects of weather and condition. Clim Res 35:5-23

Pulido F, Berthold P (2004) Microevolutionary response to climatic change. Adv Ecol Res 35:151-183

Rabøl J, Rahbek C (2002) Population trends in the Baltic passerine migrants elucidated by a combination of ringing data and point- and summer-count indices. Dan Ornitol Foren Tidsskr 96:15-38

Rainio K, Laaksonen T, Ahola M, Vähätalo A, Lehikoinen E (2006) Climatic responses in spring migration of boreal and arctic birds in relation to wintering area and taxonomy. J Avian Biol 37:507-515

Rubolini D, Spina F, Saino N (2004) Protandry and sexual dimorphism in trans-Saharan migratory birds. Behav Ecol 15:592-601

Rubolini D, Møller AP, Rainio K, Lehikoinen E (2007) Intraspecific consistency and geographic variability in temporal trends of spring migration phenology among European bird species. Clim Res 35:135-146

Spottiswoode CN, Tøttrup AP, Coppack T (2006) Sexual selection predicts advancement of avian spring migration in response to climate change. Proc R Soc Lond B Biol Sci 273:3023-3029

Stenseth NC, Ottersen G, Hurrell JW, Mysterud A and others (2003) Studying climate effects on ecology through the use of climate indices: the North Atlantic Oscillation, El Niño Southern Oscillation and beyond. Proc R Soc Lond B Biol Sci 270:2087-2096

Stervander M, Lindström Å, Jonzén N, Andersson A (2005) Timing of spring migration in birds: long-term trends, North Atlantic Oscillation and the significance of different migration routes. J Avian Biol 36:210-221

Thorup K, Tøttrup AP, Rahbek C (2007) Patterns of phenological changes in migratory birds. Oecologia 151:697-703

Tøttrup AP, Thorup K, Rahbek C (2006) Patterns of change in timing of spring migration in North European songbird populations. J Avian Biol 37:84-92

Vähätalo A, Rainio K, Lehikoinen A, Lehikoinen E (2004) Spring arrival of birds depends on the North Atlantic Oscillation. J Avian Biol 35:210-216

van Noordwijk AJ (2003) Climate change-the earlier bird. Nature 422:29

Visser ME, Both C, Lambrechts MM (2004) Global climate change leads to mistimed avian reproduction. Adv Ecol Res 35:89-110

Walther GR, Post E, Convey P, Menzel A and others (2002) Ecological responses to recent climate change. Nature 416:389-395

Zink G (1973) Der Zug europäischer Singvögel. Vogelzug Verlag, Möggingen 